e-ISSN: 1981-4755

DOI: $10.5935 / 1981-4755.20170001$

\title{
Memória e Criação nas Relações Dialógicas de Professores em Formação
}

\author{
Memory and Creation in the Dialogical Relations of Teachers in \\ Formation \\ Nelita Bortolotto* \\ *Universidade Federal de Santa Catarina, UFSC, Florianópolis - SC, 88010970, e-mail: \\ nelbortolotto@gmail.com
}

RESUMO: Focaliza-se neste trabalho os modos do ensino e de formação de professores, sua retórica (configurações arquitetônicas e tensões) para, desse lugar discursivo, contraporem-se marcas externas em torno das quais se estabelecem os discursos escritos do sujeito que fala, de sua palavra e da de outrem no ato pedagógico. O encontro entre o dado e o novo, isto é, do que é memória e do que é criação no ato da palavra que aproxima sujeito e experiência é tela para olhar as implicações e consequências no cotidiano da relação linguagem e cognição (conhecimento), experiência e ética. A abordagem dialógica da linguagem de que trata Bakhtin e seu Círculo, e seus desdobramentos, são aportes possíveis para o entendimento do que se produz ou reproduz nas relações sociais como modos de viver a vida verbal e, por ela, a vida dos sujeitos em formação (ser social).

PALAVRAS-CHAVE: Memória. Ensino. Formação de professores. Conhecimento. Experiência

ABSTRACT: The focus of this work is the teaching methods, and teachers' formation ones, their rhetoric (architectural configurations and tensions) to contrast external marks from this discursive place, around of which are established written discourses of the subject-speaking, his word and the other's, into the pedagogical act. The encounter between the old's (datum) and the new, namely, what are memory and creation in the act of the word that approximates subject and the experience, is an open screen for looking at the implications and consequences in the routine of the relation language-cognition (knowledge) and experience and ethics. The language's dialogical approach, and its outcomes, embodied by Bakhtin and his Circle are possible contributions to the understanding of what is produced, or reproduced, inside the social relations as methods of living a verbal life and by it the life of subjects in formation (the social being).

KEYWORDS: Memory. Teaching. Teachers' formation. Knowledge. Experience. 


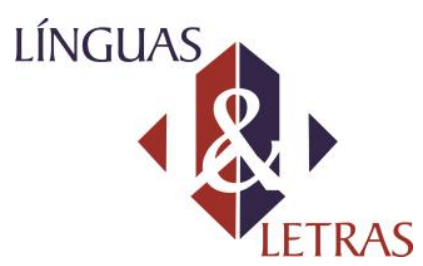

e-ISSN: 1981-4755

DOI: $10.5935 / 1981-4755.20170001$

O efetivo ato criador do autor (como aliás qualquer ato em linhas gerais) sempre se move nas fronteiras (axiológicas) do mundo estético, da realidade (realidade do dado - realidade estética), na fronteira do corpo, na fronteira da alma, move-se no espírito; o espírito ainda não existe; para ele tudo ainda está por vir; para ele tudo o que existe já houve. (BAKHTIN, 2003).

\section{INTRODUÇÃO}

Falar dos modos do ensino e da formação de professores, sua retórica quanto ao ato pedagógico, é, de certo modo, tocar em tema de investigação abarcado por muitos no contexto da educação, seja no âmbito da América ou de outros continentes. Mas todos, em boa medida, ainda temos desafios para a compreensão da travessia do ato de ensinar a ensinar; do aprender a ensinar. Para este texto ${ }^{1}$ pretendo trazer o debate do encontro entre o dado e o novo, isto é, do que é memória e do que é criação no ato que aproxima sujeito e experiência (labor profissional). Busco delinear, então, as implicações e consequências no cotidiano da relação linguagem e cognição (conhecimento), experiência e ética, pela ótica da experiência da docência de alunos brasileiros em formação inicial em nível de graduação em licenciatura em Letras-Português ${ }^{2}$ e do que dessa experiência é dito e, por este dito, refletido ou refratado. Para tanto, será foco do olhar certos sentidos que circulam na prática da docência nesse processo que é o de constituição do sujeito quando em processo de formação profissional para a docência em âmbito individual e coletivo.

$\mathrm{O}$ entendimento de memória que pretendo tratar neste trabalho diz respeito ao campo das Ciências Humanas, mais especificamente às contribuições de Mikhail Mikhailovich Bakhtin, dimensionando esse fenômeno (memória) pelas implicações na constituição dos sujeitos. Não pretendo, nos limites deste trabalho, abordar aspectos conceituais de memória pela perspectiva de estudos como da neurociência, nem mesmo

\footnotetext{
${ }^{1}$ Esta é uma versão ampliada do trabalho apresentado pelo(a) autor(a) no Simpósio Práticas letradas acadêmicas (mobilizadas) na formação inicial e continuada de professores do IV Writing Reaserch Across Border - IV - WRAB realizado em fevereiro de 2016 em Bogotá, Colômbia.

2 Neste trabalho os nomes dos acadêmicos são fictícios. Foram analisados sete ensaios produzidos por acadêmicos do curso de "Letras - Língua Portuguesa e Literatura" de uma universidade pública de âmbito federal, sob minha coordenação no papel de professora supervisora universitária. O gênero ensaio foi proposto como atividade final da disciplina "Estágio de Ensino de Língua Portuguesa e Literatura I" e embora este fosse o gênero solicitado aos estudantes não discutirei no âmbito deste trabalho o alcance ou não desse gênero pelos estudantes.
}

Volume 18

Número 39 
tratar ou cobrir caminhos que este tema já percorreu nos círculos do conhecimento humano em áreas que não sejam a da linguagem humana ou que não estejam voltadas para a compreensão do real processo da comunicação verbal humana e sua cultura.

Aceitando, pois, a dimensão histórica e ideológica da linguagem advogada por Bakhtin (Volochínov) (1990), parece oportuno trazer para este trabalho - ainda que de forma um tanto pontual e aligeirada - referências a estudos da Linguagem transversalizados com outros campos de conhecimento, como da História, que tem interesse determinante sobre o papel da memória na constituição do homem social. Aqui, evidentemente, não desejando adentrar o campo específico dos estudos da História como campo específico no universo do conhecimento humano - para o que se exigiria abordagens teóricas aprofundadas -, minha intenção é, pelo olhar "entre" fronteiras, e por certo complexas, observar a Linguagem e a relação do homem com ela, evitando, talvez, incorrer no risco do "olhar cego", porque engessado em um ou outro limite. Isso é desafio.

\section{LINGUAGEM E EXTERIORIDADE}

Na década de 1970, especialmente com a presença do livro Marxismo e Filosofia da Linguagem de Mikhail Mikhailovich Bakhtin (BAKHTIN (Volochínov), 1990), os estudos da linguagem no Brasil desencadearam pensamentos reflexivos e profundos a respeito da concepção de linguagem, atribuindo ao curso do pensamento filosófico da linguagem o componente constitutivo de produção histórica e ideológica, contrapondo-se a fontes de estudos tradicionais pouco ou em nada comprometidas com sujeitos socialmente situados, portanto, com o social, a história, a cultura, a ideologia ${ }^{3}$. É a Bakhtin (Volochinov) (1990), nesse caso e até onde se tem conhecimento, a dívida quanto à defesa de uma exterioridade constitutiva da linguagem. Sua tese é de que "a língua é um fenômeno puramente histórico" $($ p.109) e a "A palavra é o fenômeno ideológico por excelência” (p.36). Esta relação de exterioridade trazida pelo autor à compreensão da linguagem certamente revolveu, - e desde a sua época -, os estudos desse fenômeno que dimensionavam sobremaneira a explicação da língua pelo compromisso privilegiado com uma suposta "objetividade"

\footnotetext{
${ }^{3}$ Ideologia compreendida aqui como valores culturais, éticos, sócio-históricos.

${ }^{4}$ Bakhtin no conjunto de sua obra, para signo linguístico (social; ideológico; histórico) ora refere-se a termos conceituais como: língua; linguagem; palavra; texto; discurso; enunciado.
}

Volume 18

Número 39 


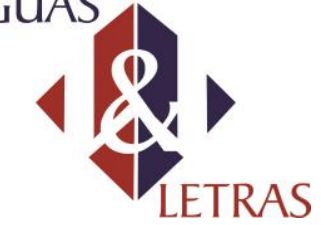

e-ISSN: 1981-4755

DOI: $10.5935 / 1981-4755.20170001$

mediante a qual a língua era figurada na sua imanência (ou melhor dizendo, como objeto formal, específico da linguística - primazia do material; alheio a bases históricoideológicas) e não na sua integralidade concreta e viva. Bakhtin (Volochínov) (1990, p. 108-109), em seu texto, sustentou a tese de que "A enunciação é de natureza social." (grifos do autor).

A ultrapassagem dos domínios da linguagem do campo da língua em sua imanência enseja a compreensão do fenômeno que é a linguagem, alçando o campo amplo das ciências nominadas de Ciências Humanas, aquele interessado em pensamentos e vivências, sentidos e significados do eu, dos de outros (BAKHTIN, 2003). Na rede dialógica o homem se expressa e o faz através de textos. Essa é a realidade imediata para a compreensão do homem social: o texto. Como diz Bakhtin (2003, p. 312),

O homem em sua especificidade humana sempre exprime a si mesmo (fala), isto é, cria texto (ainda que potencial). [...] A atitude do homem é um texto em potencial e pode ser compreendida (como atitude humana e não ação física) unicamente no contexto dialógico da própria época (como réplica, como posição semântica, como sistema de motivos).

E, como ele diz, nessa vivência, não há texto sem um sujeito, um autor, assim como se reconhece ali os legados dessa vivência, os legados do processo do pensamento na integração tempo e espaço na vida humana (conhecimento do presente, enriquecido pelas vivências do passado, com a consciência do futuro). Se analisarmos o que o homem produz necessitaremos de um olhar "alongado", que tenha em conta nesse olhar, portanto, o presente na sua relação com o passado e futuro, o olhar pelo "grande tempo" (BAKHTIN, 2003, p.410).

Assim sendo, estudar a palavra (texto/discurso) é estudar a natureza das relações dialógicas e o que delas decorre; é estudar o que se define como eu e como outro e a relação destes entre si. O outro não necessariamente é o interlocutor mais próximo, ele pode ser um interlocutor representante da cultura, do social, do ideológico. Há, portanto, a inesgotabilidade da segunda consciência, aquela que compreende e responde, tal como defende Bakhtin (2003, p.372). O autor destaca a importância do diálogo, justamente provocando para ir além de estudos específicos da linguística dado que seu interesse investigativo pelo qual advoga são os "campos limítrofes", as relações dialógicas. No seu 
entender, as relações dialógicas são importantes para todos os campos de estudo das ciências humanas e sociais porque são determinantes para a compreensão do homem social.

O que enunciamos como seres sociais - o discurso -, "é puro produto da interação social, quer se trate de um ato de fala determinado pela situação imediata ou pelo contexto mais amplo que constitui o conjunto das condições de vida de uma determinada comunidade linguística." (BAKHTIN (Volochínov), 1990 p.121). O lastro do que é proferido (oralmente ou por escrito) necessita ser figurado no contexto das retóricas individuais e comunitárias, no alcance das experiências culturais para prestar-se, cada enunciado a seu modo, a possíveis contrapalavras, a relações dialógicas. A natureza do enunciado é dialógica e este pressupõe ser compreendido "no grande diálogo da comunicação discursiva" (BAKHTIN, 2003, p. 323). Isso porque a história da cultura humana se arquiteta, pelas entranhas, no pensamento dos homens, na sua memória, agindo sobre indivíduos e em sua coletividade, que se ocupam com a atualização, (re)acentuação ou negação (conscientemente ou não) dos sentidos propalados. Contudo, é oportuna a ressalva de que, se por um lado os indivíduos pensam e enunciam apoiados em já ditos, também ela, a memória do que já está lá, pode vir a promover movimentos de abertura, para um pensamento outro, para uma ação outra, como potência do agir para a criação. Dessa forma, o ato humano e o que nele subjaz percorre uma irremediável relação cronotópica. Esta, por sua vez, é condição para compreensão do sujeito e ato, sua realidade e potência para a criação, para a produção, para a inovação. $\mathrm{O}$ diálogo entre eu e outro seria, então, modo de conhecimento, porque nele há o encontro de duas consciências que se tocam quando do encontro das vozes. Há, pois, uma memória constituinte do homem que expressa, no homem que expressa; há uma presença "falante”, “aberta”, em formação, aquela dos discursos que antecederam ao que ora é formulado, atuando no próprio projeto discursivo desse falante na sua "presentidade": uma memória dos discursos sociais; um dialogismo constituinte. A linguagem do homem traz em si a memória da uma comunidade discursiva de que é partícipe tanto nesse tempo de "presentidade" ou no tempo longo (grande tempo). O sujeito já nasce em um mundo discursivo no qual a palavra "já está lá", nasce na relação com outros. Sua linguagem por que social, cultural, não se estabelece autonomamente; ele, sujeito, pode, isso sim, vir a constituir autoria, uma palavra-própria,

\footnotetext{
5 “presentidade": termo tomado de Morson \& Emerson (2008, p. 65); “O tempo é aberto, e cada momento encerra possibilidades múltiplas".
}

Volume 18

Número 39 
ciente da sua inscrição na relação com outros sujeitos, com outros discursos e transversalizada pelos usos sociais de diferentes esferas sociais com as quais estabeleça diálogo.

\section{TEMPO E ESPAÇO NA COMPREENSÃO ATIVA ENTRE SUJEITOS}

A compreensão do tempo e espaço e destes em relação à linguagem na cultura humana é mote genuíno da tese de Bakhtin para a compreensão do vivenciamento humano do eu e do outro no mundo da vida, no mundo da cultura. Conhecer o eu e o outro, o que nessa relação está envolvido evoca a observância dos sentidos que ali circulam, calibrados pelas portas do cronotopo. Eu e outro são, cada qual, fontes disponíveis de conhecimento e na relação que estabelecem entre si se "traduzem" mutuamente, dado que um teria sobre o outro um "excedente de visão" (Bakhtin, 2003). Um e outro veem do outro o que não podem ver de si próprios. Ambos conquistam a condição para a completude de um eu para com um outro (eu-para-mim, eu-para-o-outro e do outro-para-mim), alçada no diálogo; conquistam a possibilidade do conhecimento situada na exterioridade (pelo "fora"). Tratase, consequentemente, de um encontro de sentidos potencialmente infinitos; um encontro de sentidos possíveis no campo da comunicação humana, uma vez que:

[...] A mim não são dadas as minhas fronteiras temporais e espaciais, mas o outro me é dado integralmente. Eu vivo em um mundo espacial, neste sempre se encontra o outro. As diferenças de espaço e tempo do eu e do outro. Elas existem na sensação viva mas o pensamento abstrato as oblitera. O pensamento cria um mundo único e geral do homem independentemente do eu e do outro.

[...] $\mathrm{O}$ eu se esconde no outro e nos outros, quer ser apenas outro para os outros, entrar até o fim no mundo dos outros como outro, livrar-se do fardo de eu único (eu-para-si) no mundo. (BAKHTIN, 2003, p.3 83, grifos do autor).

Ocorre que nessa condição de exterioridade necessária à compreensão do outro é requerido, como aponta Volkova, interpretando Bakhtin (apud EMERSON, 2003), o entendimento de que não se trata de ir até o outro e lá estabelecer cópia do vivido pelo outro, mas trata-se de penetração na visão de mundo do outro, para, "com a lembrança desse outro no horizonte", retornar ao seu lugar." (p.255). A autora complementa observando a necessidade desse retorno, porque é por ele que se "recupera o excesso, ou 
excedente, de visão" que distingue o eu em face do outro (p.255). Essa possibilidade de conclusão adquirida pela posição de exterioridade é que, para Volkova (apud EMERSON, 2003), provê "potencial estético", situação com ocorrência também nos nossos atos cotidianos a exemplo de "quando julgamos, quando terminamos nossa parte numa tarefa conjunta, quando apresentamos nossas congratulações (ou nossos reclamos), quando contamos uma história com um final definido" (p.255). A ressalva da autora a essa condição interessa sobremaneira neste trabalho em razão da sua importância no campo das ciências humanas: Volkova, nas palavras de Emerson (2003), afirma que "esses gestos [acima referidos] são muitas vezes unilaterais, oportunísticos, guiados por necessidades e estados de ânimo transitórios. A pessoa do outro raramente é valiosa para nós em sua totalidade, mas apenas naquele seu aspecto que está voltado ao nosso desejo ou à tarefa que temos em mãos. "Não é fácil ver uma pessoa como totalidade [tselestno] na vida cotidiana." [Volkova parafraseando Bakhtin]" (p.255).

Holquist $(2015)^{6}$, interpretando o papel do tempo-espaço na tese dialógica de Bakhtin, explana e reforça a ideia de que na teoria desse autor o tempo-espaço é que atribui distinção entre eu e o outro. Portanto, o tempo e o espaço em Bakhtin figurariam, como "formas da própria realidade efetiva", estabelecendo-se como núcleo do conhecimento e definidores do sujeito cognoscente. Nessa direção e explicitando o pensamento de Bakhtin, aclara Holquist (2015, p. 46):

É o "tempo-espaço" que define a distinção primordial entre mim e o outro, que ele [Bakhtin] define invocando os termos kantianos dado/criado [...]. "Minhas fronteiras espaciais e temporais não me são dadas, mas o outro é completamente dado". Adentro o mundo espacial, mas o outro já o está habitando.

Pela perspectiva da teoria bakhtiniana, a compreensão da relação do "eu para mim" e do "eu para o outro" demarca uma virada na compreensão do que no campo social e cultural da humanidade se vinha admitindo como consciência do eu, do outro, qual seja, a de um ser a completude do outro em sua constituição dialógica. Continuando, nessa mesma linha de raciocínio, o "ponto de vista" é tomado como cronotópico e abrange tanto o elemento espacial quanto o temporal.

\footnotetext{
${ }^{6}$ Para uma discussão mais detalhada do conceito de cronotopo em obras de Bakhtin, confira: Holquist, Michael. A fuga do cronotopo. In: BEMONG, Nele, et al. Bakhtin e o Cronotopo: reflexões , aplicações, perspectivas. São Paulo: Parábola, 2015.
}

Volume 18

Número 39 
Esse entendimento do "ponto de vista" como situado em um tempo e espaço (distanciamento cultural - inclusão do modo do outro ver pelo nosso contexto apreciativo) tinge consciências e vozes dos homens em suas relações interpessoais correspondentes.

Na relação alteritária é legítimo, então, afirmar que o "excedente de visão" elemento de completude do eu e do outro - fornece os índices de como se fundam memória e criação como experiências interdependentes e vivas na constituição dos sujeitos, no tempo e no espaço, com seus valores na cultura, na e pela linguagem.

\section{MEMÓRIA E CRIAÇÃO - RELAÇÕES ENTRE O DADO E O NOVO}

Como visto até aqui, Bakhtin e membros do seu Círculo atribuem à figura do outro, o interlocutor (o ouvinte, contemplador, auditório social etc. - real ou presumido) a condição concreta da comunicação discursiva. Bakhtin argumenta que na existência humana a possibilidade da pesquisa e do pensamento convocaria a compreensão criadora. Ao outro se impregna, portando, a possibilidade de sentido, pois nele se condensa a própria comunicação, ou seja, a compreensão criadora de um eu a um outro. Nas suas palavras,

A compreensão criadora não renunciará a si mesma, ao seu lugar no tempo, à sua cultura, e nada esquece. A grande causa para a compreensão é a distância do indivíduo que compreende - no tempo, no espaço, na cultura - em relação àquilo que ele pretende compreender de forma criativa. Isso porque o próprio homem não consegue perceber de verdade e assimilar integralmente nem a sua própria imagem externa, nenhum espelho ou foto o ajudarão; sua autêntica imagem externa pode ser vista e entendida apenas por outras pessoas, graças à distância espacial e ao fato de serem outras. (BAKHTIN, 2003, p. 365-366, grifo do autor).

Bakhtin (2003) destaca, porque valora, a presença da memória do outro na minha memória, no meu dizer. O indivíduo ocupa um lugar específico no tempo, no espaço e na cultura e desse lugar, distanciado de si, reflete e refrata as vozes dos outros nas suas. O autor advoga "a importância de uma separatividade do indivíduo, seu lugar específico no tempo, no espaço e na cultura. Não o corpo coletivo das pessoas, mas o corpo separado de uma pessoa interagindo com os outros e sendo moldado por elas [...]" (MORSON; EMERSON, 2008, p. 244). Essa seria a condição para a criação, para a dialogia entre o dado e o novo na cadeia discursiva humana, na cadeia do conhecimento humano. 


\section{LETRAS}

Em nota de rodapé a um de seus textos que trata de estética literária ${ }^{7}$, Bakhtin (2002, p. 212), dialogando com Kant e dele, em parte, divergindo, põe em evidência sua compreensão de conhecimento e, no desenho de tempo e espaço (cronotopia), o entendimento do processo em que se dá a implicação entre memória e criação:

Na sua "Estética Transcendental" (uma das partes básicas da Crítica da Razão Pura) Kant define o espaço e o tempo como formas indispensáveis de qualquer conhecimento, partindo de percepções e representações elementares. Tomamos a apreciação de Kant do significado destas formas no processo de conhecimento, mas nós as compreendemos, diferentemente de Kant, não como "transcendentais", mas como formas da própria realidade efetiva [...]. (BAKHTIN, 2002, p. 212, grifo no autor, nota de rodapé).

Nessa nota de esclarecimento o autor firma seu posicionamento correlacionando-o ao de Kant no que diz respeito à compreensão de ambos para tempo e espaço como formas no processo de conhecimento da formação do homem social. Bakhtin se alinha ao pensamento de Kant quando este argumenta que a relação tempo-espaço é categoria definidora do sujeito, no entanto, discorda quando o filósofo a defende como transcendental. Bakhtin, de seu lado, sustenta que se trata de uma relação de transgrediência $^{8}$ alicerçada na realidade concreta da vida e não de transcendência concebida como algo não engajado à realidade. Na constituição da relação $e u$ - outro esta é uma relação de transgrediência, de excedência de visão definida como acontecimento; acontecimento do ser. Como explicitam Clark e Holquist (2004, p. 102-103), a experiência exotópica do eu em relação ao outro é de aditamentos de um em relação ao outro, pois "estou ao mesmo tempo dentro e fora da outra pessoa [...] Do depósito que abriga o meu "excedente de visão" sou capaz de prover aqueles traços que são negados ao próprio paciente, visto que ele não pode ser transgrediente a si mesmo.”.

Há, pois, também presente no horizonte contemporâneo do enunciado linguístico, alerta-nos Bakhtin, uma memória que circula na relação eu/outro, como horizonte de criação ideológica, de inovação, do grupo social da época a que pertencemos. Afinal, como afirmam Morson e Emerson (2008, p. 315), assumindo as palavras de Bakhtin, "aquilo que

\footnotetext{
${ }^{7}$ Embora as reflexões de Bakhtin recaiam sobre temas voltados aos estudos literários, suas ideias podem ser estendidas a outros estudos da cultura humana.

${ }^{8}$ Nas palavras de Holquist (2015, p. 48-49), "Transgrediência [...] é o nome dum limite que, através da interação (ou da mudança de lugar) pode ser superada - transgredida - na experiência”. Bakhtin também nomina este estado de "extralocalidade" (CLARK; HOLQUIST, 2004).
}

Volume 18

Número 39 


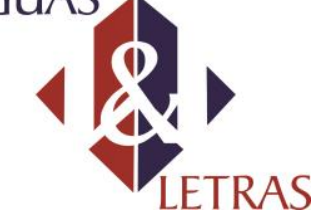

e-ISSN: 1981-4755

DOI: $10.5935 / 1981-4755.20170001$

tomou forma ao longo dos séculos pode também ter o potencial para entrar em diálogos novos e significativos com séculos e culturas posteriores.”.

\section{MEMÓRIA E LINGUAGEM - SUJEITO E EXPERIÊNCIA}

Como diz Bakhtin, ninguém é Adão bíblico que irá dizer a primeira palavra. As nossas palavras são ou já foram palavras de outros inscritas na memória, no grande tempo, mas imprimimos nelas a nossa assinatura (valoração). Bakhtin, sublinham Morson e Emerson (2008, p. 244), em seus últimos escritos passa a ter "um interesse renovado pela memória", concebendo-a "como uma acumulação assistemática de experiência passada que existe não só para a preservação mas também para a transformação criadora.”.

Vou apoiar-me na interpretação de Bakhtin à obra de Goethe alusiva à questão do tempo e da criatividade e o que desses conceitos se tributa ao entendimento da memória, pois é com base nesse conhecimento que a mim interessa pensar sobre a natureza da ação do homem social e o sentido do que é dado, do que é criação mesmo que neste particular Bakhtin estivesse sobremaneira dando ênfase a reflexões sobre obras literárias, uma produção estética do homem em seu tempo.

É especialmente com base na obra de Goethe que Bakhtin formulou o seu conceito de cronotopia, afirmam Morson e Emerson (2008, p. 431). Na visão desses autores "Bakhtin julga que Goethe compreendeu adequadamente que uma percepção real da criatividade teria de envolver o trabalho humano - 'homem, o construtor' [...]. Ela [a criatividade] deve envolver a obra que decorre de necessidades concretas ${ }^{9}$, mas que produz algo de genuinamente novo e que não é exaustivamente especificado no passado".

No que é dito há uma memória contida de já-ditos, - memória do gênero - para o que o falante, em experiências individuais que vivencia, responde ativamente em "interação constante e contínua com os enunciados individuais dos outros" (BAKHTIN, 2003, p. 294). De um lado ou de outro, na condição de indivíduos e de um coletivo, são palavras de outros que assimilamos, reelaboramos, reacentuamos com "grau vário de alteridade". Retomando palavras de Bakhtin (2003), Bortolotto (2007) assim expressa:

\footnotetext{
${ }^{9}$ Bakhtin insere a necessidade no contexto complexo do entendimento da "criatividade"; a necessidade é "uma necessidade materialmente criativa, histórica [...]. O termo necessidade é empregado em oposição a uma concepção inspiracional ou utópica da criatividade" (MORSON; EMERSON 2008, p. 431, grifos dos autores).
}

Volume 18

Número 39 
Uma das características especiais desse mundo sígnico é a existência, em cada época, até no "micromundo familiar", de enunciados exemplares (com "autoridade") que vão marcar os enunciados novos, que vão ser inspiração para uns e outros, em qualquer campo de atividade que se queira. Constituem aquilo que se chama "tradição", exemplarmente apresentada através de provérbios, aforismos, sentenças, lemas, slogans. Ou seja, o sujeito se desenvolve em ambientes repletos de linguagem, e entra nesse fluxo praticamente sem o perceber (naturalização), aprendendo não meramente as palavras em seu invólucro lingüístico, mas tons, valores, expressividade - discurso. É a isso que Bakhtin chama "processo de assimilação - mais ou menos criador - das palavras do outro (e não das palavras da língua)" (BAKHTIN, 2003, p. 294). Aqui ele está salientando, naquilo que é "assimilado", o tom valorativo do discurso, que pode ser reelaborado e reacentuado - ou seja, que pode ir além da palavra da tradição, da autoridade. (BORTOLOTTO, 2007, p. 39, grifo do autor).

O enunciado dos indivíduos, em sua expressividade (tom valorativo) que é assimilado, reelaborado e reacentuado "ou é uma expressão típica de gênero, ou um eco de uma expressão individual alheia, que torna a palavra uma espécie de representante da plenitude do enunciado do outro como posição valorativa determinada" (BAKHTIN, 2003, p. 295). O indivíduo ao enunciar-se traz uma posição valorativa (pelo que é "o dado"), desse modo, nessa fala, há a sua assinatura com a participação no fluxo do dizer (abertura para "o novo"). A criatividade do modo como defende Bakhtin, nas palavras de Morson e Emerson (2008, p. 244), "requer tanto a acumulação gradual da experiência pessoal real quanto a existência de outros genuínos como a base para a verdadeira aprendizagem. Num espírito quase estóico, Bakhtin reconhece que os indivíduos nunca estão inteiramente à mercê dos acontecimentos desde que conservem o poder de reconcebê-los". Ainda interpretando Bakhtin em sua compreensão de "plenitude do tempo", ou seja, "a conexão interna do passado, do presente e do futuro" e a "natureza da criatividade", assim expressam os dois autores:

Ações e acontecimentos respondem a qualquer momento a circunstâncias específicas nas quais ocorrem e se criam novas circunstâncias, que proporcionam constrições e oportunidades para uma ação futura. [...] Bakhtin usou o termo tempo longo para referir-se à percepção de que os eventos passados, quando se tornam congelados em instituições, linguagens de heteroglossia e gêneros, suscitam problemas específicos e oferecem recursos também específicos para cada momento presente que se segue. Não se pode entender uma obra ou uma ação "encerrando-a" inteiramente no seu próprio momento. (MORSON; EMERSON 2008, p. 430). 
De seu lado, Morson e Emerson (2008, p. 430-431) afirmam que a criatividade, entendida no contexto desse proferido "tempo longo", é um acontecimento constante, não podendo ser compreendida como “erupções súbitas, misteriosas, vindas de lugar nenhum.”. É “uma resposta a problemas que se apresentam em circunstâncias particulares num tempo particular." [...] A criatividade se enraíza nas ações reais de pessoas reais, que usam os recursos fornecidos pelo passado [...] de uma criatividade anterior [...]”.

Bakhtin (2003, p.364), outra vez tocando no tema da literatura, expõe que "O autor é um prisioneiro de sua época, de sua atualidade.", mas, ao mesmo tempo, pondera sobre sua liberdade: "Os tempos posteriores o libertam dessa prisão, e os estudos literários têm a incumbência dessa libertação". Contudo, argumenta o autor, não se pode "ignorar inteiramente a época contemporânea do escritor, que a sua obra não possa ter irradiações no passado e projeções no futuro. "A atualidade mantém o seu significado imenso e em muitos sentidos decisivo.”. A plenitude de uma obra só se revela no grande tempo. (BAKHTIN, 2003, p. 364, grifos do autor). Portanto, a cultura de uma época não pode ser fechada em si mesma, dado que "a unidade de uma cultura é uma unidade aberta". Os sentidos estão jacentes no passado cultural das épocas. (BAKHTIN, 2003, p. 364, grifos do autor)

As palavras de Morson e Emerson (2008, p. 244-245) que seguem são esclarecedoras quando interpretam sobre a liberdade que tem o eu e outro na produção da palavra:

A descrição da liberdade por Bakhtin [...] tem tudo o ver com a nãocoincidência. Desde que se possa mapear a diferença entre o eu e um outro eu, e entre o passado lembrado da pessoa e uma reavaliação criadora desse passado, a pessoa possui as condições para a criatividade e a liberdade. Necessitamos das limitações do nosso próprio passado e dos outros eus.

Pelo que se depreende das reflexões no curso deste texto, a perspectiva de memória abordada por Bakhtin é relacional, expressa o continuum do passado, presente e futuro, no acontecimento dialógico do eu-outro. Nesse continuum, indivíduo e sociedade, se constituem como tal porque cada qual carrega consigo memórias de uma tradição impressa como consciência instituída no coletivo (oficial ou privada); a consciência de que há uma tradição que se instala no corpo e na alma dos indivíduos e coletividade. Uma tradição que se transveste de conhecimentos institucionalizados (oficiais) e, em muito, representativos de certos grupos ou indivíduos, com interesses privados. Algo que oportuniza observar os 
conhecimentos pelo modo como se formulam e se estabelecem na vida do indivíduo e coletividade, como se fundam em conhecimentos institucionalizados, oficiais e em certas tradições formais ou não. Temos muito a aprender com a memória em sua história. Como diz Le Goff (2013, p. 437), em uma lição dos estudos da História, “A memória, na qual cresce a história, que por sua vez a alimenta, procura salvar o passado para servir ao presente e ao futuro. Devemos trabalhar de forma que a memória coletiva sirva para a libertação e não para a servidão dos homens.”. Somando essa lição à de Bakhtin, podemos recriar os sentidos da memória produzindo novos sentidos no presente, com perspectivas de um virtuoso futuro.

\section{A MEMÓRIA NA EXPERIÊNCIA PROFISSIONAL DE ESTÁGIO DE DOCÊNCIA}

Retomando os caminhos teóricos que venho expondo ao longo da escrita deste texto e o ponto que aqui focalizo, a memória pela perspectiva conceitual do "grande tempo" (presente, passado, futuro) e "memória dos gêneros" pareceu-me oportuno ter trazido à tona esse pano de fundo teórico para observar o caráter peculiar do discurso do profissional que ensina a língua portuguesa, quando vive a experiência de ser professor no momento do estágio curricular supervisionado de Português. Entendo ser a teoria do dialogismo de Bakhtin um aporte substancial para a compreensão do tema da memória no que tange particularmente às relações entre conhecimento e experiência profissional docente com compromisso com o ensino e a aprendizagem, quando se assume uma profissão e por ela a condição de quem forma outros e, concomitantemente, a si próprio.

Em vivências dessa natureza estudantes universitários, na condição de profissionais do campo de ensino pela adesão a cursos de Licenciatura, assumem disciplinas constantes do currículo da cultura escolar, no nosso caso, do Brasil. O estudante, então, na função de professor-estagiário irá conviver em sala de aula esse duplo papel, o de aluno universitário e de professor-estagiário. Ele será aluno e professor ao mesmo tempo. Vivenciará o trabalho docente e a formação de professor em concomitância, convivendo com estudantes da escola de educação básica e com outros profissionais, quais sejam, o professor da turma em que irá atuar, o professor supervisor (da escola) e o professor supervisor universitário. Ambos com papéis sociais e formativos distintos, mas semelhantes ao assumirem a função 
de avaliadores da experiência profissional do acadêmico, com legitimidade institucional para aprová-lo ou não.

Os cursos de Licenciatura têm seus Projetos Político-Pedagógicos (PPP) com base nos quais são desenvolvidas as ações das universidades que tenham sob sua responsabilidade tais cursos. No caso dos dados que apresentarei aqui, estes são advindos de um curso de Letras de uma universidade de âmbito da federação brasileira em cujo PPP consta como atribuição do estágio “o exercício da análise da realidade educacional brasileira" e "o exercício da docência" (PPP do Curso de Letras [*] ${ }^{10}, 2006$, p. 19). Estão delineadas para o estágio supervisionado as seguintes etapas: "definição do campo de estágio; planejamento: observação de aulas e elaboração de projetos de trabalho; docência em sala de aula e em atividades extraclasse; elaboração de relatórios e ensaio; socialização e avaliação" (Plano de Ensino, 2015). As vozes dos professores-estagiários que trarei para análise constam da escrita dos seus ensaios em que expõem a experiência de estágio docente concluída ${ }^{11}$.

Imerso na realidade do contexto escolar, o aluno está diante de um legado cultural real que se edifica na memória dos sujeitos fundando representações sobre o que é ser um profissional docente, sobre qual a natureza do objeto do seu ensino (sobre a complexidade do ato de ensinar e de aprender). $\mathrm{O}$ aluno universitário foi aluno do ensino básico para o qual terá o compromisso do trabalho profissional de professor de...; carrega, portanto, representações - como aluno que foi desse nível de ensino, mas também tem o compromisso de dar conta de (re)elaborar aquilo que aprendeu na universidade como conhecimento para si (agora como professor) e para seus alunos do ensino básico (aqueles que estarão sob sua responsabilidade no estágio e vida profissional). Terá de lidar com as memórias de largo tempo, aquelas que foram sendo construídas com as experiências pessoais de escolar, como aluno, ou advindas da experiência no coletivo, em relações nos grupos sociais fora da universidade ou nessa comunidade acadêmica. Nesse fluxo, não

${ }^{10} \mathrm{O}$ nome da instituição de ensino superior foi omitido.

11 Para os propósitos desse texto não será objeto de análise a organização da disciplina e estágio supervisionado de Português. Quanto à experiência da escrita do gênero "ensaio" é oportuno destacar que a perspectiva assumida para a orientação dirigia à escrita dos estudantes que frequentam a disciplina em tela que é por mim ministrada é aquela que advoga Foucault (1994), que pode assim ser resumida: O ensaio ou a "atividade filosófica" - conforme Foucault - vem a ser o trabalho crítico do pensamento sobre o próprio pensamento. É tentar ir além, ou seja, pensar diferentemente em vez de legitimar o que se sabe.

Volume 18

Número 39 
dissonante a tudo isso, ainda se lida com o que se desenha como tradição (das experiências pessoais e de grupos inteiros).

Há que considerar também que o presente do ensino institucionalizado possui marcas de vozes do passado e nele vem sobrevivendo certo domínio interpretativo em torno do qual são ora propostas rupturas, como também outras rupturas são propostas em certas ordens vigentes.

Especificamente no que diz respeito ao ensino da língua portuguesa, no contexto do ensino institucionalizado vem se desenvolvendo certo modo de tratamento no domínio das metodologias de referência para esse ensino, costumeiramente identificado como rupturas de um status quo. Propõe-se rupturas metodológicas no ensino que são mais, posso arriscar a dizer, não-rupturas (ou tentativas de...) mas, às vezes, uma espécie de fratura do modo de trabalho vigente. A alegação é de ultrapassagem, no presente, de um passado que não serviria mais. Com um "agora é diferente" instituído sob base na negativa do outro modo (o tradicional) de ensinar, se vem enunciando muitas "novidades" metodológicas e de tratamento do objeto de ensino, sem talvez, como nos alerta Bakhtin, penetrarmos (aqui um mea culpa) nas "profundezas dos seus sentidos" que a cultura escolar e acadêmica (que institucionalmente tem a responsabilidade de ensinar a ensinar) estariam possivelmente nos indicando, afastando com isso possibilidades de desenvolvimento da compreensão criadora.

Defendemos aqui o olhar-pelo-movimento do eu e do outro no acontecimento da comunicação pelas frestas cronotópicas, preceito que Bakhtin (2003) nos trouxe dos estudos de Goethe e que agora coopto como possibilidade para olharmos o aluno-professor em sua formação profissional no seu trabalho da docência. Na leitura de Bakhtin sobre Goethe, como visto neste trabalho, o tempo e o espaço aparecem como indissociáveis e como "processo de formação". Acrescento:

A simples continuidade temporal (neben einander) dos fenômenos era para Goethe profundamente estranha, ele a saturava, a penetrava de tempo, descobria nela o processo de formação, o desenvolvimento, distribuía em série o que estava distribuído no espaço por diferentes fases temporais, épocas de formação $(8)^{12}$. Para ele, a atualidade - tanto na natureza quanto na vida humana - se manifesta como uma essencial diversidade de tempos: como remanescentes ou relíquias dos diferentes graus e formações do passado e como embriões de um futuro mais ou menos distante. [...] o olho que vê procura e encontra em toda a parte o tempo - o desenvolvimento, a

\footnotetext{
12 “(8) Veja-se a caracterização da visão criadora de Goethe em oposição à visão de Dostoiévski no livro Problemas da obra de Dostoiévski (p.48).” (BAKHTIN, 2003, p.444)

Volume 18

Número 39
} 
formação, a história. Por trás do acabado ele enxerga o que está em formação e em preparo [...]. (BAKHTIN, 2003, p. 229).

Isso pode nos indicar que o foco que vimos dando ao problema do que vem regulando os modos de ensino e de aprendizagem na formação dos licenciandos e na sua ação como professores da educação básica poderia ser outro: a observância na relação euoutro (as relações interpessoais) do distanciamento (cronotopia), e excedência de visão, "porque o que vejo predominantemente no outro, em mim mesmo só o outro vê" (BAKHTIN, 2003, p. 22); compreender o outro sem assimilar-se a ele, sem perder a singularidade. Algo a ser mirado tocando-se nas "profundezas dos sentidos" da cultura escolar e acadêmica.

\section{O QUE FAZEMOS DA LINGUAGEM QUE APRENDEMOS NA VIDA E NA CULTURA - E É MEMÓRIA -, NO CONTEXTO DA OFICIALIDADE MAGISTERIAL CONTEMPORÂNEA?}

O distanciamento entre $e u$ e outro que estabelece o excedente de visão e o estado de conhecimento implicados entre si são tratados por Bakhtin tanto no acontecimento estético da escrita literária, entre autor e personagem, quanto em trabalhos tardios nos quais referese à "distância do leitor contemporâneo e do pesquisador em relação a épocas e culturas distantes.” (BEZERRA, 2003, p. 426, notas). Diz Bakhtin (2003, p. 362-363, grifo do autor):

Quando tentamos interpretar e explicar uma obra apenas a partir das condições de sua época, apenas das condições da época mais próxima, nunca penetramos nas profundezas dos seus sentidos. $\mathrm{O}$ fechamento em uma época não permite compreender a futura vida da obra nos séculos subseqüientes; essa vida se apresenta como um paradoxo qualquer. As obras dissolvem as fronteiras da sua época, vivem nos séculos, isto é, no grande tempo, e além disso levam freqüentemente (as grandes obras, sempre) uma vida mais intensiva e plena que em sua atualidade.

[...]

[...] uma obra não pode viver nos séculos futuros se não reúne em si, de certo modo, os séculos passados. Se ela nascesse toda e integralmente hoje (isto é, em sua atualidade), não desse continuidade ao passado e não mantivesse com ele um vínculo substancial, não poderia viver no futuro. Tudo o que pertence apenas ao presente morre juntamente com ele. 
Qual seria, então, o nosso "vínculo substancial” na pedagogia da língua portuguesa (o objeto de ensino, seus modos de ensinar, seus sentidos) que atravessaria os tempos? Qual o tempo e espaço do "enriquecimento com novos significados, novos sentidos" que "superassem o que foram na época da sua criação" (BAKHTIN, 2003, p. 363)? A lição que podemos tirar das palavras de Bakhtin, ainda, insisto, que ele estivesse falando sobre obras literárias no curso dos tempos, é que, em razão de não efetuarmos o necessário distanciamento, não temos como "perceber conscientemente e avaliar no contexto da cultura [de nossa] época" os efeitos de sentido de um ou outro ensino, de uma ou outra metodologia de um ou outro conhecimento. Estariam, pois, no campo da educação, os conhecimentos anteriores destituídos de elementos vivos, "destituídos de formas saturadas de sentidos" (BAKHTIN, 2003, p. 363)? Ou o acontecimento conjunto entre dado e novo seria uma ocorrência pertinente para o entendimento da natureza da ação pedagógica?

As queixas são muitas no campo da educação institucional de que pouco ou nada se muda; fala-se da resistência de parcela importante de profissionais a mudanças de algo que já não atenderia as necessidades da atualidade. Convive com essa máxima outra: o novo é o que interessa à atualidade. Nesse embate, muitas vezes polarizado, penso, a tese da linguagem como interação e nesse contexto o conceito de cronotopia que a envolve pode vir a ser um ponto de reflexão importante para pensar questões da educação por um enfoque que fugiria de interpretações com lastro de tradição, seja do ponto de vista do objeto ou do sujeito, do dado ou do novo, da memória ou da criação, centrado em um ou em outro desses polos.

Os ensaios acadêmicos de muitas experiências recentes de estágio supervisionado em Letras-Português direcionados ao ensino básico, como as que são objeto neste trabalho, vêm retratando um quadro um tanto dissonante entre o que a universidade ensina em seus bancos escolares e o que os professores desenvolvem em sala de aula de escolas as quais estejam vinculados. Particularmente, em experiência de estágio de docência no segundo semestre do ano de 2015, um grupo de alunos, sete ao todo, deparou-se com uma prática docente que diferiu desse quadro retratado, pois pôs-se próxima aos conhecimentos adquiridos pelos alunos até então na graduação. Algo nem sempre comum vivenciado pela maioria dos acadêmicos de Letras-Português nos últimos tempos. Na escola na qual o grupo de acadêmicos de 2015 atuou, o Projeto Político-Pedagógico do estabelecimento de ensino, desde 2002, tem tido como eixo de ação "Ler e escrever: compromisso da escola, Volume 18 Número 39 
compromisso de todas as áreas". Pressupõe-se, portanto, que os professores de todas as disciplinas da grade curricular sejam responsáveis pelo ensino e aprendizagem da leitura e da escrita naquela escola. Como lidaram, então, esses estudantes de Letras-Português com a experiência do aprender a ensinar essa língua como disciplina escolar, quando o foco esperado de partícipes da academia para a consecução da experiência profissional escolar seria a suposta "apresentação "do novo" - a criação -" , porque se propala com certa evidência no discurso pedagógico e por arautos na academia: "nós (sujeitos da academia) temos de mudar a escola que aí está!’? Pensando assim, prediz-se que os acadêmicos teriam também a responsabilidade pela "criação", pela mudança, pelo "novo". Nesse ponto cabe indagar: estaria uma cultura, a escolar, subjugada a outra, a cultura acadêmica? Um equívoco, certamente se assim o fosse. Contudo, esse grupo de estudantes, ao qual me referi há pouco, se viu diante da interface de culturas em harmonia no que se refere particularmente ao que e como ensinar na escola ${ }^{13}$. Qual seria, então, a ousadia razoável, a "profundidade semântica" a ser atingida, pela qual pudessem os estudantes vir a contribuir com o fluxo de um conhecimento que já circula na escola e que supostamente estaria trazendo bons resultados a todos os envolvidos na educação de uma comunidade escolar? O que se supõe ser o "já-dado”? O que se supõe ser o "novo"? Qual a relação entre o que é dado, com o que se busca alçar nessa parceria escola-universidade: uma "memória ativa e acumulada na sua completa plenitude semântica"? (BAKHTIN, 2002, p. 436). Ou, neste caso em específico, se trataria de atitude de convivência, de congruidade entre as culturas escolar e acadêmica? E quanto ao que é "dado" e "novo? Haveria nesse contexto a consciência da tal "profundeza semântica" a ser mobilizada? Haveria aí consciência quanto ao fomento à "compreensão criadora”? Nas narrativas ensaísticas os alunos em questão deixam transparecer que em suas vivências como docentes experienciam momentos de tensão quando ocupam diferentes posições exotópicas relacionadas umas às outras, ou seja, a de aluno de um curso de Letras, a de docente-estagiário, no exercício profissional do

\footnotetext{
${ }^{13}$ A concepção de linguagem da escola é de linguagem como interação (Bakhtin (Volochínov), 1990) em razão da qual essa instituição reserva como objeto do seu ensino o uso social dos gêneros do discurso (Bakhtin, 2003). De seu lado, estudantes de Letras (da turma em tela) no campo da pedagogia da língua portuguesa tiveram na academia formação nessa mesma direção teórica e de prática de ensino.

14،“a separação, na palavra, da realidade é destruidora para ela mesma: ela definha, perde sua profundidade semântica e sua mobilidade, sua capacidade de ampliar e de renovar seu significado em contextos novos e vivos e, em essência, morre enquanto palavra, pois a palavra significante vive fora dela mesma, isto é, vive de sua direção para o exterior" (BAKHTIN, 2003).
}

Volume 18

Número 39 
magistério. Em posições cronotrópicas distintas (tempo; espaço e na cultura), essas posições, por vezes, observo, embaciam as certezas. As vozes de Júlia e Jana, abaixo, representam essa realidade:

[...] apesar de termos escolhido a temática deste trabalho [projeto de docência], não foi uma tarefa fácil. Seja por lacunas durante a graduação ou por falta de experiência, frequentemente me senti perdida entre tantos conceitos, sem conseguir definir muito bem o que seria de fato um relato de experiência [gênero recomendado pelo professor da escola para o ensino] e temi que esta insegurança e falta de conhecimento aprofundado sobre o assunto acabasse confundindo ainda mais os alunos. Entretanto, percebi que aos poucos as coisas ficavam mais claras. Fui aprendendo enquanto tentava ensinar. E creio que aprendi muito mais do que ensinei. (Ensaio. Júlia, 2015, p. 154).

Sabia que o fazer discente daria lugar ao fazer docente, mas a pergunta que não calava era: “Como farei isso?”. Desde a pré-escola somos acostumados a assumirmos a posição de aluno, e ter que inverter os papéis me deixou aterrorizada [...] Os anos passaram e o tão temido e esperado estágio chegou. Temido, porque sempre tememos o desconhecido, e esperado porque estava a dois passos da tão sonhada formatura (Ensaio Jana, 2015, p. 145; p. 147).

Em seus ensaios, pelo que se evidencia nos excertos abaixo, a maioria dos estudantes parece compreender que o trabalho de docência passa mais pela empatia nas relações interpessoais (busca pela fusão eu/outro) ${ }^{15}$, deixando de valorar o sentido profundo implicado na relação eu/outro (a de alteridade) para atingir o conhecimento, ainda que, talvez, de forma não consciente, pois em nenhum dos ensaios essa temática fica explicitada para os possíveis leitores ${ }^{16}$. Os estagiários e a escola, em consonância com o professor efetivo da turma na qual os acadêmicos estagiaram, tomaram os gêneros do discurso (Bakhtin, 2003) em seus usos sociais como o "objeto de ensino" adequado para aquele fim, porque é considerado conhecimento largamente divulgado pela comunidade científica e acadêmica para ensinar Português (ainda que os estagiários apresentassem certa insegurança no tratamento desta questão no ato magisterial). Não houve, portanto, quanto ao que é objeto de ensino em língua portuguesa na escola nenhum estranhamento narrado. É aí que, afirmo, a cultura escolar e a acadêmica estariam em um discurso uníssono. Mas por que nada manifestaram a respeito desse objeto de ensino? Reafimaram-no apenas como

\footnotetext{
${ }^{15}$ A compreensão criadora exigiria a não identificação com o outro, exigiria que o outro fosse visto pela exterioridade (Bakhtin).

${ }^{16}$ Leitores dos relatórios de estágio que neles constam os ensaios dos estagiários.

Volume 18

Número 39
} 


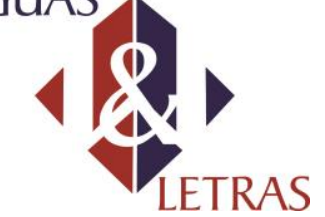

e-ISSN: 1981-4755

DOI: $10.5935 / 1981-4755.20170001$

dado, apesar de verem-se desafiados com a sua lida no cotidiano escolar. Creditamos às palavras de Bakhtin uma possível resposta a esta questão quando o autor adverte que teríamos de conservar a exterioridade evitando assim uma possível interpretação precipitada ao valorar a consciência única (monológica - individual ou coletiva), negligenciando a consciência concebida na e pela dialogia como algo que poderia vir a enriquecer o ato humano ou a sua interpretação, pois, mesmo na concordância esta incidiria sobre pontos de vista diferentes. O encontro potente rumo ao outro, a observância da potência eu/outro na escuta implicada (dever ético) pode nos acordar do trivial, estranhar o óbvio, o mesmo, e originar questões inesperadas.

Seguindo o que estava no planejamento da professora regente de Português, decidimos trabalhar o relato de experiência escrito com o sétimo ano matutino, a turma $71[\ldots]$ Já no período do estágio de observação, eu e minha colega [Júlia] havíamos percebido o quão difícil e desafiador seria trabalhar com uma turma - falante e agitada - composta por 31 alunos. Sabíamos que, infelizmente, não poderíamos atender muitos ao mesmo tempo, muito menos individualmente - como fizemos no período de docência extraclasse - o que dificultaria o nosso trabalho. Acredito que a nossa parceria, a qual se baseou em respeito, confiança e companheirismo, foi essencial para uma boa interação com os alunos, sem a qual não seríamos capazes de desenvolver um bom trabalho. (Ensaio Paula, 2015, p. 157).

Os conceitos e teorias discutidos nas disciplinas da graduação não se bastam para formar um profissional educador em excelência.

[...] Não alcancei, nas disciplinas da graduação, fundamentação teórica mais próxima da realidade escolar do que aquela resultada de minha própria vivência no estágio. [...] $\mathrm{Na}$ observação, percebemos o quanto a classe era produtiva e amadurecida, principalmente em se tratando de trabalhados escritos. Isso nos incentivou a preparar um projeto que aproveitasse ao máximo esta qualidade e nos permitisse ensinar pela mediação individual, dos alunos. (Ensaio Mariana, 2015, p. 166).

Felizmente a escola na qual atuamos como estagiária não tinha uma tendência ao estudo gramatical e nem era vidrada nas práticas de tipologia textual: Narração, descrição e dissertação. [...] Para entender o trabalho com os gêneros e poder trabalhá-los com os alunos, os conceitos de Bakhtin vinham à minha mente; ok, e agora? O que fazer com eles? Eu queria que as aulas realmente acontecessem. [...] A escola tinha o costume de excluir os alunos com maiores dificuldades, isso os levava a pensar que não eram capazes de aprender e nem de produzir nenhum tipo de conhecimento. O professor precisa estar atento às diferenças, capacitar-se, estar aberto ao novo, enxergar os seus alunos e compartilhar os saberes. (Ensaio Renata, 2015, p. 142; p.143).

Volume 18

Número 39 
O discente, assim como o docente precisam ouvir, aprender e ensinar, tudo é uma troca, e faz parte do desenvolvimento do ser humano. Sendo assim, o que guardo dessa experiência são os momentos de confiança; aprendizado; e amizade. (Ensaio Jana, 2015, p. 147).

Se gêneros do discurso como objeto de ensino, por um lado, é um ponto importante de discussão para os fins da pedagogia da língua portuguesa para as duas instituições, por outro, seria esse o "vínculo substancial" que ora trazemos para discussão por que intentamos compreendê-lo (a centralidade no objeto do ensino)? Os escritos dos estudantes apontam que eles se sentem "esse ser" que "inova" que traz o "novo para a sala de aula", mas o identificam como sendo o ensino dos gêneros do discurso em seus espaços sociais de uso. Isso seria o novo aprendizado do aprendiz do ensino, advindo dos estudos da academia (ainda que não por todos), confirmado pela escola; na escola. No conjunto das posições dos alunos em seus ensaios não ficou evidenciado que estes entendem a inter-relação verbal e social do eu e do outro como a propulsora das investidas exitosas que tiveram na docência (em nível de relações interpessoais e de cognição - conhecimento), bem como que tenha sido ela a motivadora que ratificou a certeza da opção profissional para a carreira do magistério - o trabalho com o outro. Seria ainda subliminar esse entendimento? Não seria esse o "vínculo substancial" - o compromisso com o diálogo - subsumido no discurso ensaístico e no discurso real em sala de aula com vistas à compreensão do ato magisterial? Não estaria aqui assentada a compreensão criadora de que falava Bakhtin em seus escritos? Aquela constituída pela não-coincidência do eu e do outro, de não estarem subjugados um ao outro no ato magisterial? Afinal, como já nos alertou Bakhtin, "a palavra quer ser ouvida, entendida, respondida e mais uma vez responder à resposta, e assim ad infinitum.”. Quando forças contraditórias abertas à escuta se encontram, não seria aí que se estabeleceria a "inovação"? Não será essa a memória que permanece produtiva e que nela e por ela, "inova" - aquela de conhecimentos outros, do conhecimento do outro; do conhecimento de si ("Minhas fronteiras espaciais e temporais não me são dadas, mas o outro é completamente dado" (Bakhtin)) e que faz de nós todos do campo da educação uma comunidade de pessoas ocupadas em ensinar e em aprender, indo além da representação da escola como instituição responsável pela transmissão da memória coletiva? Argumentação forte e verdadeira, é certo. Não seria a memória coletiva mais provocadora de 
aproximações e de distanciamentos entre eu e outro reafirmando a criatividade e a liberdade no tempo, no espaço e na cultura?

\section{EPÍLOGO - QUAL O SENTIDO DE OLHAR NA DIREÇÃO DO PASSADO PARA COMPREENDER O PRESENTE?}

É imperativo reconhecer a importância da compreensão criadora (ativa) da arquitetônica do ato do homem que materializa ética e estética no seu existir com vistas à liberdade da construção de um olhar outro sobre o mundo e de como com ele nos relacionamos, dialogamos.

Bakhtin nos apresenta, como profissionais ocupados com as ciências humanas - no nosso caso a educação -, esse desafio, o da compreensão criadora (responsável), do ir às profundezas dos sentidos, nos desafia à ousadia investigatória, à mobilização transgrediente. Nos desafia que façamos perguntas e empreendamos compreensões ativas, deslocados do nosso lugar, olhando pelas fronteiras de um tempo e espaço históricos; pelo distanciamento não indiferente do outro, mas com a responsabilidade ética para ir até o outro e de lá voltar com a memória encharcada de sentidos (e não com a cópia dela), abrangendo com esse ato a responsabilidade de constituir-se com o outro, como outro na e pela cultura escolar; na cultura escolar. Com um potencial estético (não indiferente) em mãos é possível deflagrar propostas de ensino implicadas com a memória do que já-está-lá (memória do indivíduo; da coletividade), do que está aqui ("presentidade"), constituindo um ensino comprometido não com abstrações, mas com base no real vivido, processado pela excedência de visão do sujeito que ensina (transgrediência) apresentando ao estudante um devir outro, uma forma e acabamento que jamais atingiriam seja o professor ou seu aluno na solitude do eu-para-si: "É preciso que o professor renove-se e recrie-se sempre! [...] O estágio pode ser entendido como um preparo, o início de toda uma trajetória, mas é, também, o momento de questionar e questionar-se, de avaliar, e avaliar-se" [Ensaio Mariana, 2015, p. 167- 168). 


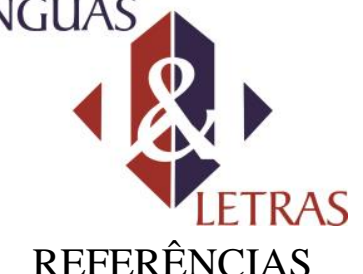

e-ISSN: 1981-4755

DOI: $10.5935 / 1981-4755.20170001$

BAKHTIN, Mikhail (V. N. Volochínov). Marxismo e filosofia da linguagem: problemas fundamentais do método sociológico na ciência da linguagem. 5. ed. São Paulo: Hucitec, 1990.

. Estética da criação verbal. Tradução do russo sw Paulo Bezerra. 4. ed. São Paulo: Martins Fontes, 2003. (Coleção biblioteca universal).

- Questões de literatura e estética: a teoria do romance. Tradução de Aurora Fornoni Bernardini et al. 5. ed. São Paulo: Hucitec Annablume, 2002.

BRAIT, Beth. O discurso sob o olhar de Bakhtin. In: GREGOLIN, M. R.; BARONAS, R. Análise do discurso: as materialidades do sentido. São Paulo: Claraluz, 2003.

BORTOLOTTO, Nelita. O sentido da ciência no ato pedagógico: conhecimento teórico na prática social. 2007. 239 f. Tese (Doutorado) - Universidade Federal de Santa Catarina, Florianópolis, 2007.

EMERSON, Caryl. Os cem primeiros anos de Mikhail Bakhtin. Tradução de Pedro Jorgenen Jr. Rio de Janeiro: DIFEL, 2003.

FOUCAULT, Michel. História da sexualidade: o uso dos prazeres. Tradução de Maria Thereza da Costa Albuquerque. 7. ed. Rio de Janeiro: Graal, 1994. v. 2.

HOLQUIST, Michael. A fuga do cronotopo. In: BEMONG, Nele et al. Bakhtin $e o$ Cronotopo: reflexões, aplicações, perspectivas. Tradução de Oziris Borges Filho et al. São Paulo: Parábola, 2015.

LE GOFF, Jacques. História e memória. Tradução de Bernardo Leitão et al. 7. ed. Campinas, SP: Editora da Unicamp, 2013.

MORSON, Gary Saul; EMERSON, Caryl. Mikhail Bakhtin: criação de uma prosaística. Tradução de Antonio de Pádua Danesi. São Paulo: Editora da USP, 2008.

Data de recebimento: 28/04/2017

Data de aprovação: 23/05/2017 